\title{
Competency management in Slovenia: Paradoxes between development trends and drivers of change*
}

\author{
Jürgen Mühlbacher, Michaela Nettekoven, Jure Kovac**
}

The focus of the transitional processes in CEE studies has changed in recent years. One important study area in the transitional processes in CEE is the construction of a globally competitive economy structure and increased efficiency of the rule of law. An important element of the competitiveness of companies is individual competency management. Especially in transition economies like Slovenia, human resources have to be regarded as a key factor for the current and future success of the economy. This article presents the study results that include managers' opinions regarding the connections between the external and internal drivers of change and influencing competency management in Slovenia.

In den letzten Jahren hat sich der Schwerpunkt bei der Erforschung der Transitionsprozesse in MOE geändert. Im Vordergrund stehen nicht mehr Studien zur Transformation in eine Marktwirtschaft, sondern die Konstruktion einer global wettbewerbsfähigen Wirtschaftstruktur und die Umsetzung eines Rechtsstaates nach europäischem Muster. Ein wichtiges Element der Wettbewerbsfähigkeit von Unternehmen ist das individuelle Kompetenzmanagement. Insbesondere in Transitionsökonomien wie Slowenien müssen die Arbeitskräfte als ein Schlüsselfaktor für den gegenwärtigen und den zukünftigen Erfolg einer Wirtschaftskraft betrachtet werden. Im Beitrag werden Forschungsergebnisse vorgestellt, die den Standpunkt von Managern im Zusammenhang mit externen und internen Treibern der Veränderungen vorstellen sowie deren Einfluss auf das Kompetenzmanagement in Slowenien.

Keywords: Competency management, human resources, transition economies, Slovenia

* Manuscript received: 26.01.10, accepted: 22.10 .10 (1 revision)

** Jürgen Mühlbacher, Prof. Dr., WU Vienna University of Economics and Business, Vienna, Austria. Main research interests: Competence management, change management, knowledge management and emerging markets. Corresponding address: juergen.muehlbach@wu.ac.at.

Michaela Nettekoven, Associate Prof., WU Vienna University of Economics and Business, Vienna, Austria. Main research interests: Finance, quantitative methods and dicision theory. Jure Kovac, Prof., Faculty of Organizational Sciences, University of Maribor, Slovenia. Main research aress: organization theory, management development and organizational design. 


\section{Introduction}

Almost two decades of research on transitional processes in the CEE has produced extensive studies on changes in these countries. It is true that the first and greatest interest in studies of transitional processes in the CEE has already passed. However, new and interesting findings regarding the processes of social transformation are still appearing. Consequently, today we have numerous extensive studies from the field of transitional processes in the CEE (Aslund 2002; Galenson 2004; Gabrisch/Hölscher 2005; Berglöf/Roland 2007; Bluhm/Trappmann 2008, Bafoil/Turner 2009).

A special place within the research of restructuring economic systems in transition countries belongs to the study of management (Lungwitz 1998; Edwards/Lawrence 2000; Geib/Pfaff 2000; Lohr 2003; Bluhm 2007; Dickmann et al. 2008; Lang et al. 2009; Karoliny et al. 2009). Managers were particularly exposed to the processes of restructuring economic structures. Due to the privatisation processes and the current consolidation of ownership structures, managers in the transition environment have frequently found themselves taking over key initiatives in directing the development of their organisations. We often denote them as "change agents" or accelerators of business transition processes (Lang et al. 2001).

In the area of studying managers and their roles concerning change processes in transition countries, the role and significance of their competencies has become, not merely a short-term trend, but a necessary, integral part of the strategic planning for the sustained development of the organisation. Individual competency management occupies a special place in the construction of the competitive capacities of the organisation. Especially in transition economies like Slovenia, human resources have to be regarded as a key factor for the present and future success of the economy. Therefore, our study will focus on the following research question: Which management competencies do Slovenian managers have and how are these competencies influenced by external and internal drivers of change?

\section{Theoretical basis}

\section{Competency management}

Competency management represents a holistic field of research, ranging from strategic to organisational to individual competencies (Elliot/Dweck 2005; Tidd 2006; Mühlbacher 2007). The following focuses on the definition of individual competency and the historical development of competency classes, both of which are needed to answer our research question. Due to the limited space of this article, a number of interesting aspects will have to be omitted here and left to future research. 
The definition of competency changes with each theory used, i.e., it has a fixed meaning only within the specific construct of a particular competency theory. Competencies in a narrow sense are the dispositions of self-organised actions. As they are internal, unobservable dispositions, competencies are always subjective characteristics, attributed on the basis of problem and solution orientation, by informing a person of an objective - without a specific solution - and then measuring the degree to which the objective was achieved. Competency is defined here as accomplishing or even exceeding a set objective (Erpenbeck/von Rosenstiel 2003). The most important objectives of professional competency development are the establishment and promotion of professional action competency. Here, the integration of cognitive, emotionalmotivational, volitional and social aspects of human behaviour in work situations is the main focus of interest (Heyse 1997).

Recent work on individual competency management (Probst et al. 2000; Sarges 2001; Erpenbeck/von Rosenstiel 2003) primarily emphasises the fact that competencies are strongly oriented towards the future. This enables a person to tackle upcoming challenges, whose nature cannot be predicted or determined, in a self-organised manner. Thus, discussions regarding competencies are of importance whenever strategic personnel planning and development take centre stage in times of great uncertainty.

The seminal works of Bartlett and Goshal (1997) or Brown and Eisenhardt (1998) show the need for the adaptation of management competencies based on an increase of speed and complexity in the organisational environment and vice versa - a lack of flexibility and innovation within organisations. What is still missing throughout the competency literature is an empirical study concerning the drivers of change and their influence on individual management competencies. This is precisely the main purpose of our study.

This also requires a change in perspective within human resource management. Both the current requirements and the competencies necessary in the future have to become the focal point of the analysis and must be seen as a strategic competitive advantage for the company (McCall 1998; Nahapiet/Sumantra 1998). From this point of view, the question of in which specific competencies a company should invest in order to realise value added in the future - in the sense of return on investment - at first remains unanswered. Only the answer to this question, however, makes it possible to use further education as a strategic instrument of management development.

Particularly regarding anticipated competencies, one should keep in mind that this data - in accordance with a Delphi study - are explorative prognoses. Apart, therefore, from the comparison of the current distribution of competencies, this study, therefore, can only serve the function of generating hypotheses. 


\section{Classes of competencies}

An early differentiation of competencies was made by Jacobs (1989:36), who distinguishes between "hard and soft competencies." Hard competencies refer, for example, to analytical and organisational capabilities, while creativity and sensitivity are soft competencies. From this, Jacobs develops the argument that hard competencies result in observable behaviour, with the invisible, but dominant soft competencies underlying them. The principles of this conviction, though conceivable, are difficult to prove and thus this conception has been classified as an artificial differentiation with low explanatory potential in the theoretical discussion (Woodruffe 1993).

To avoid this criticism, a categorisation of the knowledge, capabilities, properties and abilities required has prevailed, first consisting of three - still without the category of self- and personal competency (Sloane 1998) - and later four areas of competency, which meets both the theoretical and pragmatic requirements (Heyse 1997). A clearer description of these four classes of competencies can be found in Sonntag and Schaper (1999).

All these categorisations have been reworked. In newer classifications, for instance, functional and methodological competencies are combined, because of their proximity and the desired generation of a general competency model, which separates self-dispositive actions from personal dispositions and introduces the new class, i.e., that of leadership competency. As a result, the following five classes of competencies can be distinguished (Kasper et al. 2005):

- Self-dispositive competencies, which represent the self-organised use of one's own resources (time, know-how etc.)

- Methodological competencies, comprising all analytical and solutionoriented behaviours

- Social-communicative competencies, covering the area of social interaction (excluding leadership)

- Leadership competencies, including the full range of leadership, motivation and personnel development

- Personal competencies, mainly manifesting themselves in extraordinary personality traits

Based on this classification, the empirical data are coded and then, in a second step, analysed with regard to the influence of the external and the internal environment, in order to answer our research question. 


\section{Empirical Analysis}

\section{Introduction}

The core of the questionnaire focused on two open questions on the management competencies deemed necessary at present and in the future. Two further open questions asked for external and internal drivers of change, which would influence the individual competencies within the next three to five years. The interviewees defined the competencies and drivers themselves and, in a second step, also had to weigh the competencies with a percentage value and to mark the drivers as opportunity or threat. The answers of the open questions were coded with Mühlbacher's category scheme (2007).

Figure 1. Functional areas of the interviewees (SLO)

\begin{tabular}{|c|c|}
\hline Industry & Share in per cent \\
\hline Consumer goods & $26.1 \%$ \\
\hline Public sector & $16.2 \%$ \\
\hline Trade & $15.3 \%$ \\
\hline Banking and insurance & $9.0 \%$ \\
\hline Capital goods & $6.3 \%$ \\
\hline Consulting & $3.6 \%$ \\
\hline IT \& telecommunications & $2.7 \%$ \\
\hline Chemical \& pharmaceutical industry & $2.7 \%$ \\
\hline Other (e.g., sewage enterprises, health and culture organisations) & $18.0 \%$ \\
\hline Total: & $100.0 \%$ \\
\hline
\end{tabular}

The questionnaire was sent to 550 participants of executive management courses of the University of Maribor in Kranj, Slovenia. A total of $N=111$ questionnaires were returned, which represents a response rate of roughly $20.1 \%$. Questionnaires were collected at the beginning of the financial crisis, i.e., from the second half of 2008 until the first half of 2009 .

Figure 2. Functional areas of the interviewees (SLO)

\begin{tabular}{|c|c|}
\hline Functional area & Frequency \\
\hline Organisation & 26 \\
\hline Project Management & 25 \\
\hline Finance \& Controlling & 22 \\
\hline Marketing & 17 \\
\hline Human Resource Management & 17 \\
\hline Production & 16 \\
\hline Logistic \& Supply Chain Management & 13 \\
\hline IT & 13 \\
\hline Research \& Development & 6 \\
\hline Others & 16 \\
\hline
\end{tabular}


Fifty of the 111 persons interviewed were male and 61 female. It is interesting that the share of top female managers (with 22 interviewees) was substantially higher than the number of their male counterparts (nine interviewees). The sample of middle management is composed of 41 men and 39 women. The average age of top managers (both male and female) is 43.8 years, with their ages ranging between 27 and 60 years. This value also coincides with the statistical development of top Slovene management becoming younger in recent years (Statistical Office of the Republic of Slovenia 2009).

The average age of middle managers (both male and female) is 43.15 years and is, similar to top management, between 26 and 59 years. This shows that Slovenia has recently witnessed a generation renewal. Top and middle managers are now approximately of the same age, which has brought about a substantial decrease in career prospects for middle managers. Consequences of this development will be discussed at the end of this article. Figure 1 represents the distribution, broken down by industry.

Concerning their functions, Slovenian managers are anchored in 1.5 functions on average, while in the Czech Republic this value is recorded at 1.9 (Mühlbacher et al. 2009) and in Austria at 2.4 (Mühlbacher 2007). We can conclude from this that the most explicit functional specialisation of management so far can be found in Slovenia (Figure 2).

\section{External and internal drivers of change}

A first approximation of the perceived change can be found in the analysis of external and internal drivers of change. Regarding external drivers of change, the following figure provides an overview of all responses given by Slovenian managers.

By far the most positive estimate can be seen in innovation. This is followed by an equally positive estimate of market changes and restructuring, which may nevertheless also be taken as negative. The labour market shows an increasing, negative tendency, while the economic position represents the strongest negative weighting factor.

The way of life is perceived as strongly positive, whereas globalisation and corporate policy are merely moderately positive. The second strongest negative external driving force is the development of prices in Slovenia. For Slovenia, which is a model of a successful transition economy, environmental protection is solely a positive virtue, whereas social demographic development is considered positive, but with some reserve. What are clearly negative are the influence of politicians and trade unions, as well as the introduction of new laws. The interviewees regard the EU as positive, while the financial crisis is definitively negative. Eastward expansion is also perceived rather negatively. The overview of external factors of changes concludes with the lack of resources and growing pace. 
In contrast to the external factors, internal drivers of change are - except from changes in HR - positively evaluated. This can, according to attribution theory, be explained by the fact that they can be influenced more easily by the managers. Thus, internal factors are seen more optimistically. All the changes listed in Figure 4 are, in most cases, initiated by management, and so it is not surprising that these factors show a high acceptance. Here again we give an overview over all responses of our interviewees.

In Slovenia, the most important internal driver of change is procedural change. In second place, the strongly negatively attributed change in human relations is found. New management tools, structural change, corporate strategy, new products or services, growth, and new owners or new management are all seen positively. Finally, motivation/empowerment, international cooperation, customer orientation, and organisational culture have positive aspects, albeit at a fairly low level.

Figure 3. External drivers of change

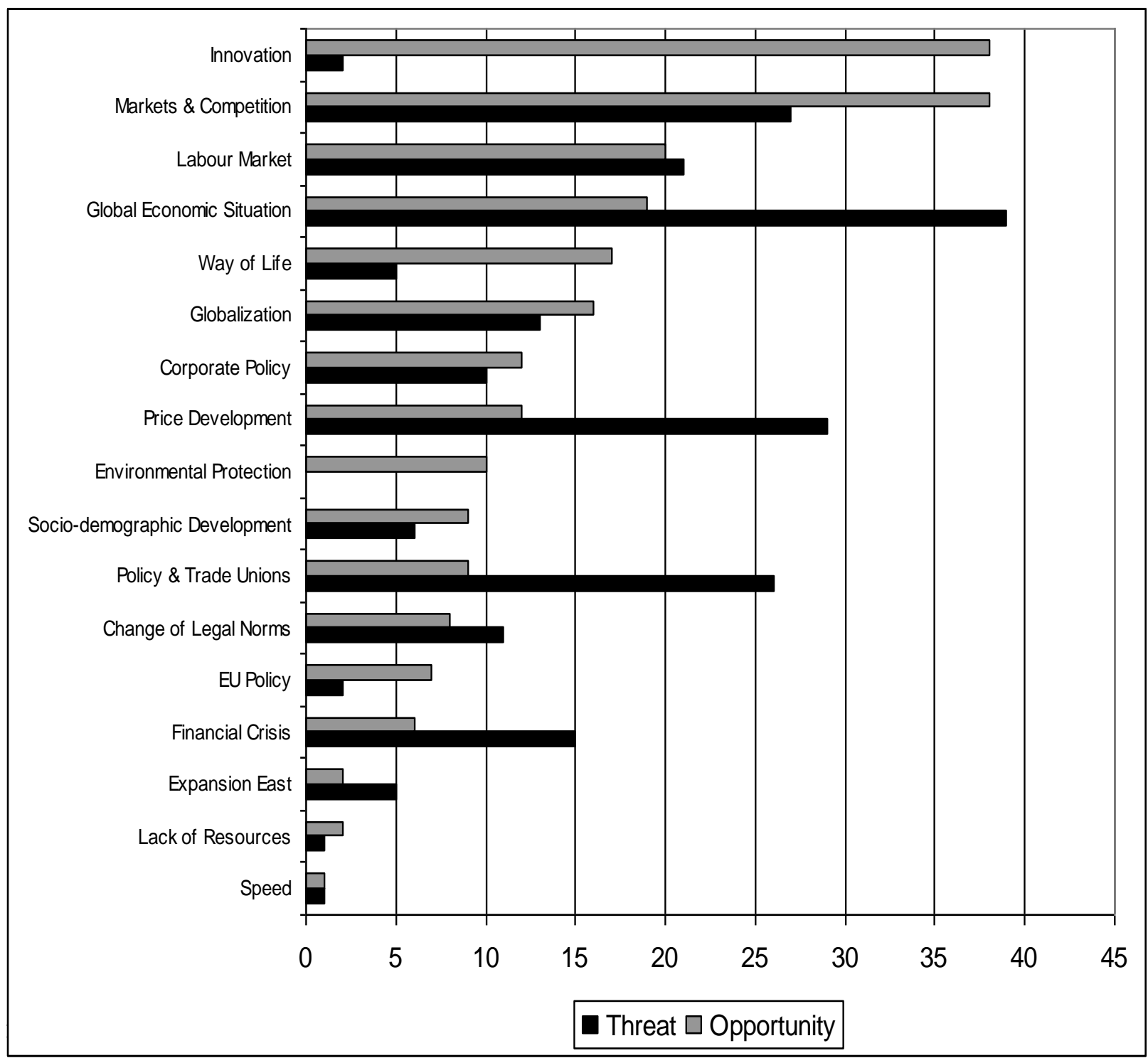




\section{Analysis of the competency classes}

An initial ranking of the individual competency classes shows (Figure 5) a clear predominance of methodological competencies, followed by leadership and social-communicative competencies, and, clearly behind, personal and selfdispositive competencies. Future rankings are expected to look very similar. The methodological competency class declines in importance but remains in first place. Leadership competencies drop slightly, but remain in second place. Social-communicative competencies remain stable, while personal and selfdispositive competencies both increase significantly in value.

\section{Figure 4. Internal drivers of change}

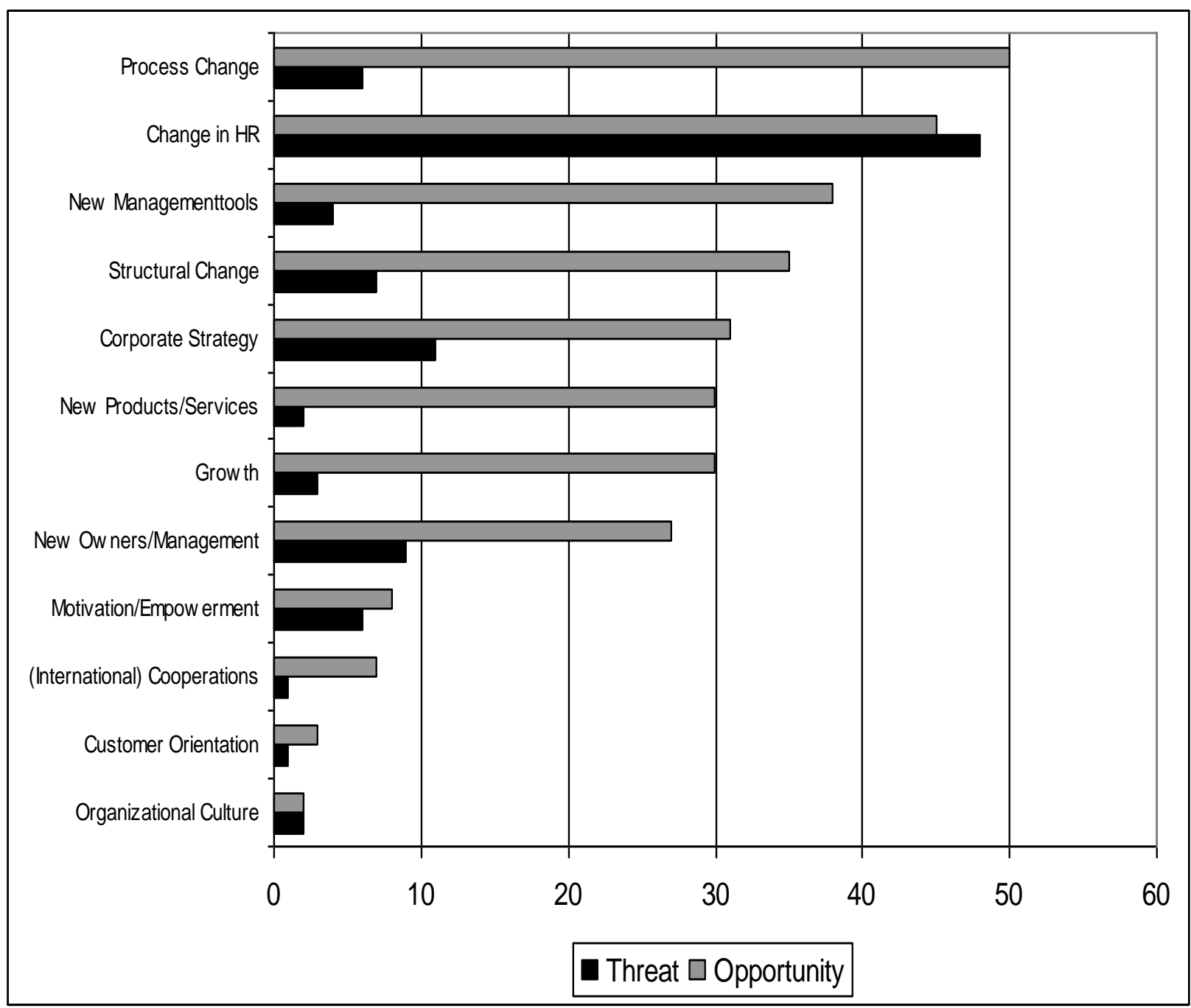

( $\mathrm{n}=725$ responses / multiple answers possible)

When analysing the differences between the assessments of those competencies currently required and those anticipated in the future, only marginally significant differences can be ascertained in the composition of competency classes. Here, the sample size must be taken into consideration; an extension of the sample planned for the future would certainly result in even greater significances. In general, the T-test with paired samples already shows that 
personal competencies and self-dispositive competencies significantly gain in importance; social-communicative competencies are nearly stable, while the other two classes of competency classes lose importance.

Figure 5. Changes in relevance of competency classes over time

\begin{tabular}{|c|c|c|c|}
\hline Competency classes & Mean Value & $\mathrm{T}$ & $\begin{array}{c}\text { Sig. } \\
\text { (2-sided) }\end{array}$ \\
\hline Methodological competencies - present & 41.2793 & \multirow{2}{*}{-1.940} & \multirow{2}{*}{0.055} \\
\hline Methodological competencies - future & 36.4595 & & \\
\hline Leadership competencies - present & 15.7477 & \multirow{2}{*}{-1.312} & \multirow{2}{*}{0.192} \\
\hline Leadership competencies - future & 13.8108 & & \\
\hline Social-communicative competencies - present & 13.7477 & \multirow{2}{*}{-0.406} & \multirow{2}{*}{0.686} \\
\hline Social-communicative competencies - future & 13.0405 & & \\
\hline Personal competencies - present & 7.4955 & \multirow{2}{*}{2.320} & \multirow{2}{*}{0.022} \\
\hline Personal competencies - future & 11.1937 & & \\
\hline Self-dispositive competencies - present & 6.9550 & \multirow{2}{*}{2.314} & \multirow{2}{*}{0.023} \\
\hline Self-dispositive competencies - future & 10.1802 & & \\
\hline
\end{tabular}

\section{Causal model of the Slovenian Sample}

If there is a lack of information on the structure of the dependencies between empirical data, the use of a dependency analysis is advisable. For this study, the TETRAD II software (Version 3.1) has been selected. This program produces a path-analytical model on the basis of a covariance or correlation matrix, which shows the acyclical graph of the directed and undirected dependencies. With continuous variables, the program assists in the search for path and structural equation models. For discrete data, TETRAD II creates and updates Bayes networks. The algorithm used is based on the so-called D-separation, in which probabilistic dependency tests are conducted, i.e., there is no confirmatory causal analysis of the model. However, this can be done later using LISREL, EQS, PLS or AMOS (Spirtes et al. 1998).

The model thus derived was tested with the help of the AMOS 5.0 software. The program was selected because it makes possible a combination of multivariate regression and ANOVA analyses, which can also be used with ordinally scaled data and do not require a strict normal distribution. The parameters of the models were estimated using the maximum-likelihood method. 
Figure. 6. Causal model of the drivers of change and their effects on the competence classes

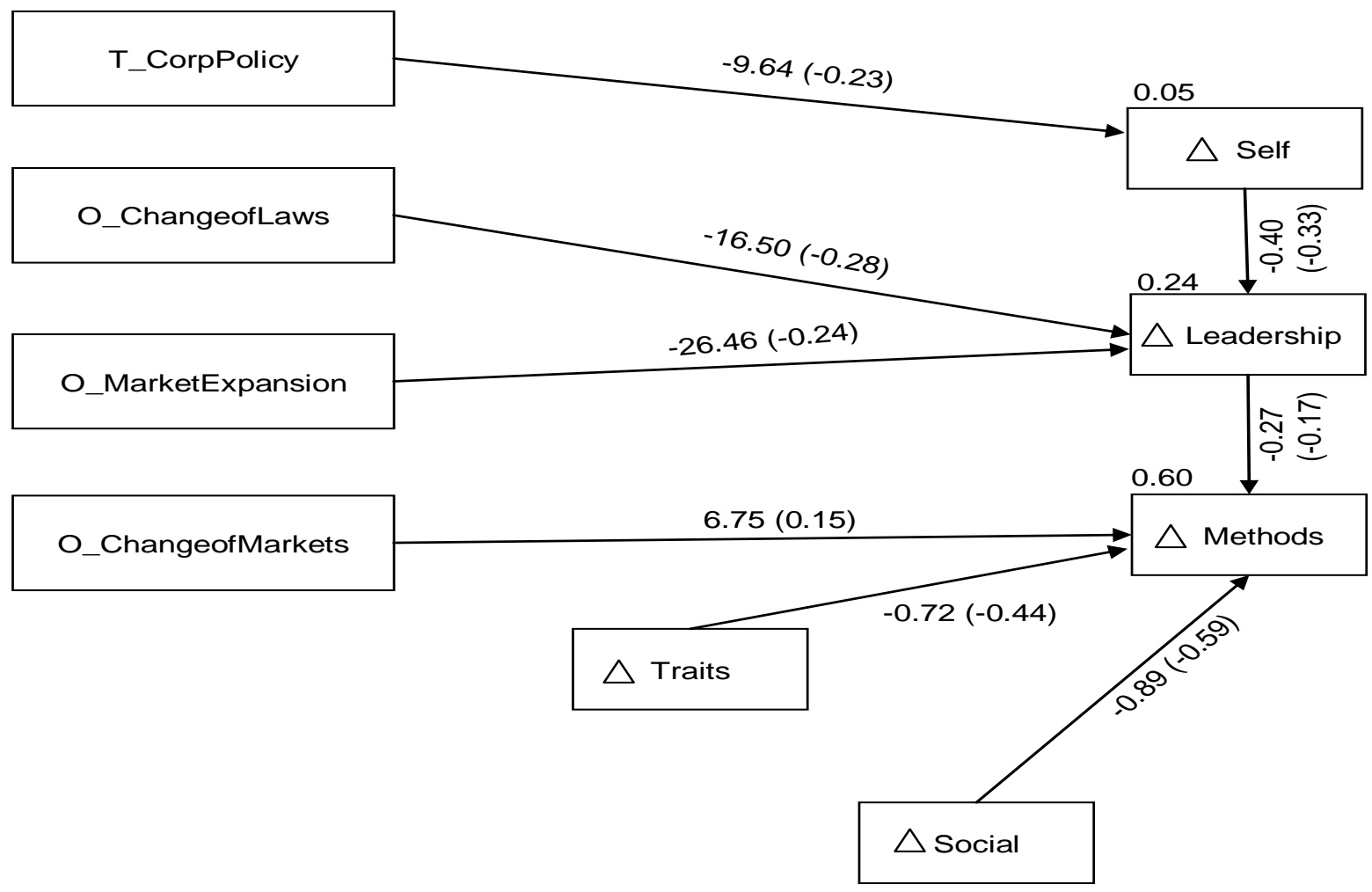

$(\mathrm{N}=111 ; \mathrm{O}=$ Opportunity; $\mathrm{T}=$ Threat $)$

T_CorpPolicy: Corporate policy seen as a threat

O_ChangeofLaws: Change of legal framework seen as an opportunity

O_MarketExpansion: Market expansion seen as an opportunity

O_ChangeofMarkets: Structural change of markets seen as an opportunity

$\Delta$ Self: Change of the importance of self-dispositive competencies (future - present)

$\Delta$ Leadership: Change of the importance of leadership competencies (future - present)

$\Delta$ Methods: Change of the importance of methodological competencies (future - present)

$\Delta$ Traits: Change of the importance of personal competencies/traits (future - present)

$\Delta$ Social: Change of the importance of social-communicative competencies (future - present)

Having established the general changes, the impact of external and internal drivers of change on the individual competency classes is to be determined next. The following illustration of the model (Figure 6) shows the significant external and internal drivers of change on the left, and the individual competency classes on the right, whose increase is mainly due to the decrease in methodological competency. The arrows represent the causal relations tested, with the first value showing the regression coefficient and the value in brackets showing the standardised $\beta$-coefficient. The value in the upper left hand corner of each variable is $R^{2}$ and states the percentage of the variance measured that can be explained by the model regarding the respective competency class. 
At first glance, it is evident that - unlike similar analyses in Austria (Mühlbacher 2007) and the Czech Republic (Mühlbacher et al. 2009) - the development of qualification is influenced merely by external driving forces of changes.

It is paradoxical that the significant increase in self-dispositive competencies cannot be found here. On the contrary, the analyses shows only a strong decrease caused by the perception of one company's policy by 10.42 percentage points $(\beta=-0.24)$. This also shows a relatively small influence with $\mathrm{R}^{2}=5 \%$.

The intermittent category of leadership competencies, which decreased by 0.40 $(\beta=-0.33)$ with the increase of self-dispositive competencies, also bears a negative effect on methodical competencies with $-0.27(\beta=-0.17)$. This category is influenced externally by a positively perceived change of legal norms with $-16.50(\beta=-0.28)$ and negatively by the expansion, particularly to the neighbouring Eastern countries, with $-28.46(\beta=-0.24)$. Direct individual leadership is thus evidently more often replaced by structural management, or rather delegation. This influences $24 \%$ of the variance between the current and expected demands.

As the sole external driving force of changes in methodical competencies, the analysis showed a positive perception of market changes and restructuring. Here, the growth led to an increase of 6.75 percentage points $(\beta=0.15)$. The decline in the sum of this qualification category can be explained with the growing significance of personal competencies with -0.72 percentage points $(\beta=-0.44)$, the influence of relatively stable social-communicative competencies with -0.89 $(\beta=-0.59)$, and the already explained negative impact of leadership competencies. The decline of the latter has a positive effect because of this inverse relation, which can again be explained with the growth of selfdispositive competencies. The variance of this qualification category can be explained with the help of all these factors by up to as much as $60 \%$.

Although the significance of personal competencies increases the most, this cannot be explained by using any internal or external driving force of changes. This is also logical as it involves stable personal characteristics. These are first developed in one's youth and are then formed into a self-image, which is questioned only in crisis situations. The growing significance can, however, be explained with the aforementioned generation renewal in Slovene management.

In the end, the social-communicative competencies also remain without internal and external weighting factors. This can be explained with a stable value of this competency class.

Analyses of the development of competency classes and the influence of internal and external driving forces of changes are thus considered extremely contradictory. In attempting to explain this, we can again state the realised generation renewal. Clearly, the renewal was the reason insufficiently qualified 
managers were offered their positions. This is balanced by a high personal use of self-dispositive competency. At the same time, the external driving forces of change, such as positively perceived factors like market changes and restructuring, changes of the legal framework, economic expansion towards the East, and a company's policy, all call for a greater professionalisation of management. This paradox currently represents the greatest challenge to the Slovene economy.

To prove the validity of the model described above, the following test has been calculated: the $\chi^{2}$ test, which, due to its high sensitivity to sample size and its intolerance in connection with deviations from a normal distribution, is often criticised, also provides conditional proof of the model. The $\chi^{2}$ value, for instance, is at $1.549(\mathrm{Cmin}=43.377$ with 28 degrees of freedom) and thus far below the required limit of 2 . Arbuckle and Wothke (2003) in this context refer explicitly to the high sensitivity of this value regarding sample size and the unrealistic assumption of a "Perfect Fit." Furthermore, the independent model produces a much worse relation of $\chi^{2}=4.037(\mathrm{Cmin}=145.327$ with 36 degrees of freedom).

Because of the criticism of the classic $\chi^{2}$ test, variants of this analysis were calculated in order to evaluate the overall quality of the model, which are relatively independent of the sample size and resistant to breaches in the assumption of a normal distribution. The Goodness-of-Fit-Index (GFI) states that the model can explain $91.2 \%$ of the variances of the original data. Taking into consideration the degrees of freedom, the Adjusted-Goodness-of-Fit-Index (AGFI) confirms that $85.9 \%$ of the variance is explained by the model, which is slightly below the recommended critical value of $90 \%$, but still acceptable.

\section{Competence change on the individual level}

In order to interpret this result in a more practical way, a paired-sample T-test is used to determine which specific competences differ significantly regarding the current and anticipated future importance. In this test, 12 values - of which, four refer to a $10 \%$ significance level - show a detectable change. The following figure lists the competences by the difference of the mean values (i.e., future minus present). 
Figure 7. Significant difference between competencies currently required and anticipated for the future

\begin{tabular}{|c|c|c|c|}
\hline Competencies & Difference of mean & $\mathrm{T}$ & Sig. (2-sided) \\
\hline Willingness to learn & 3.15315 & 3.201 & 0.002 \\
\hline Visionary thinking & 1.82883 & 1.890 & 0.061 \\
\hline Personnel development & 1.71171 & 2.009 & 0.047 \\
\hline Foreign Languages & 1.26126 & 2.315 & 0.022 \\
\hline Ability to innovate & 1.55856 & 1.755 & 0.082 \\
\hline Flexibility & 0.94595 & 2.267 & 0.025 \\
\hline Lobbying & 0.81081 & 1.899 & 0.060 \\
\hline Total Quality Management & -0.63063 & -2.007 & 0.047 \\
\hline Ability to delegate & -0.85586 & -1.933 & 0.056 \\
\hline Process management & -1.98198 & -2.402 & 0.018 \\
\hline Communication & -3.09459 & -3.101 & 0.002 \\
\hline Classic leadership skills & -3.46847 & -2.796 & 0.006 \\
\hline
\end{tabular}

$\mathrm{N}=111$

Self-dispositional willingness to learn shows the greatest increase. A weaker increase has been detected with visionary thinking. However, a visible increase has also been detected in relation to the ability to manage personnel development and in relation to the social-communicative ability of foreign languages, while the self-dispositional ability to innovate - starting from an already relatively high level - shows an increase at a 10\% significance level. A visible increase has also been detected in relation to the self-dispositional flexibility, whereas social-communicative lobbying indicates a somewhat weaker increase. Methodological competences of total quality and process management show a considerable loss of importance, as do the socialcommunicative ability to delegate, and communication. Nevertheless, the strongest decrease in importance is perceived in relation to classic leadership skills. These developments will have a great influence on the design of executive education programs and organisational career paths.

\section{Conclusion and limitations}

Finally, as the results show, research into and the practice of individual competency management are still in their early days. A common understanding regarding the competency class terminology is developing only slowly. Still, it can be seen that internal and external drivers of change have a significant influence on the competency requirements of companies. This makes it all the more important to address the topic of competency management in a focused and methodical manner. Individual and isolated measures taken in personnel development and change management approaches, which thus far have dominated organisations, are not yet sufficient. In order to maintain competitiveness, it is not only necessary for management to rethink matters, but 
also to integrate corporate strategy into the operational human resource management. Personnel development should not merely focus on adapting employees to the system, but emphasise the ability of the whole organisation to strategically renew itself and innovate.

Regarding this explorative model, a point of self-criticism has to be made in that the causalities shown cannot be fully grounded in theory, but are based on the subjective experiences of the persons interviewed. Still, they provide an inter-subjectively comprehensible picture of the reality of Slovenian managers. The high residual values and the still unexplained share in the variances can equally be criticised, as they point to further factors of influence. The aim of this analysis, however, is to create a general model of the changes in individual competency classes and the factors influencing them that are statistically verifiable.

\section{References}

Aslund, A. (2002): Building capitalism, Cambridge: Cambridge University Press.

Arbuckle, J.L. /Wothke, W. (2003): AMOS 4.0 User's Guide. 7th Print, Chicago: Small Waters.

Bafoil, F./Turner, C. (2009): Central and Eastern Europe: Europeanization and social change, New York: Palgrave MacMillan.

Bartlett, C.A./Goshal, S. (1997): The individualized corporation. New York: Harper Business.

Berglöf, E./Roland, G. (eds.) (2007): The economics of transition, Basingstoke (UK), New York: Palgrave Macmillan.

Bluhm, K. (2007): Experimentierfeld Ostmitteleuropa? Deutsche Unternehmen in Polen und der Tschechischen Republik, Wiesbaden: VS Verlag.

Bluhm, K/Trappmann,V (2007): Economic elites in enlarged Europe, in: Journal for East European Management Studies, 13 ,4, 282-290.

Brown, S.L./Eisenhardt, K.M. (1998): Competing on the edge: strategy as Structured Chaos. Harvard: Harvard Business School Press.

Dickmann, M./Brewster, C./ parrow, P. (eds.) (2008): International human resource management: A European perspective, New York: Routledge.

Edwards, V./Lawrence P. (2000): Management in Eastern Europe, Basingstoke: Macmillan. in: Elliot, A.J./Dweck, C.S. (eds.) (2005): Handbook of competency and motivation, New York: Guilford.

Erpenbeck, J./von Rosenstiel, L. (2003): Einführung, Handbuch Kompetenzmessung, Stuttgart: Schäffer-Poeschel, IX-XL.

Galenson, A. (2004): Economies in transition, Washington: The World Bank.

Gabrisch, H./Hölscher, J.(2005): Transformation to a market economy, hampshire: Palgrave Macmillan. 
Geib, P./Pfaff, L. (eds.) (2000): Strategic management in Central and Eastern Europe, New York: International Business Press.

Hartmann, M. (2007): Eliten und Macht in Europa. Ein internationaler Vergleich. Frankfurt am Main/New York: Campus.

Heyse, V. (1997): Vorbemerkung: Ziele und Hauptaussagen der Studie, Kundenbetreuung im Banken- und Finanzwesen, Münster: Waxmann, 1-11.

Jacobs, R. (1989): Getting the measure of managerial competency, in: Personnel Management, 21, 6, 32-37.

Karoliny, Z/Farkas, F./Poor, J. (2009): In focus: Hungarian and Central Eastern European characteristics of human resource management - An international comparative survery, in: Journal for East European Management Studies, 14 , 1, 9-47.

Kasper, H./Mühlbacher, J./von Rosenstiel, L. (2005): Manager-Kompetenzen im Wandel, in: Zeitschrift Führung + Organization, 74, 5, 260-264.

Lang, R./Pawlowsky, B. (eds.) (2001): Wirtschaftsethik in Mittel und Osteuropa, Arbeit, Organisation und Personal im Transformationsprozess, Band 13, Rainer Hampp Verlag, Mering.

Lang, R./Bogdanović, D./Jungnick, K./Konečna, Z./Rybnikova, I. (2009): The meaning of management in CEE countries, IX. Chemnitz East Forum, Chemnitz.

Lohr, K. (2003): Management und Managementprozesse in Ostdeutschland - Befundeund Perspektiven aus managementsoziologischer Sicht, in: Journal for East European Management Studies, 8, 4, 369-386.

Lungwitz, R. (1998): Manager als Konstrukteure organisatorischer Modernisierungs-prozesse in der Industrie Ostdeutschland, Polens und der Tschechischen Republik, in: Lang, R. (Hrsg.), Führungskräfte im osteuropäischen Transformationsprozess, München: Rainer Hammp Verlag 1998.

McCall, M.W. (1998): High flyers, developing the next generation of leaders, Boston: Harvard Business School Press.

Mühlbacher, J. (2007): Kompetenzmanagement als Grundlage strategischer Wettbewerbsvorteile. Wien: Linde.

Mühlbacher, J./Nettekoven, M./Putnová, A. (2009): Drivers of change and competence managemetn in the Czech Republic,in: Journal of Global Business and Technology, 6, $1,15-27$.

Nahapiet, J./Sumantra, G. (1998): Social capital, intellectual capital, and the organizational advantage in: Academy of Management Review, 23, 2, 242-266.

Probst, G.J.B./Deussen, A./Eppler, M.J./ Raub, St.P. (2000): Kompetenz-Management. Wie Individuen und Organizationen Kompetenz entwickeln. Wiesbaden: Gabler.

Sarges, W. (2002): Competencies statt Anforderungen - nur alter Wein in neuen Schläuchen?, in: Strategien der Personalentwicklung, Wiesbaden: Gabler, 258-300.

Schuh, A./Ploszajski, P. (2008): What the West can learn from the East. Grow East, Wien: Linde, 62-69. 
Sloane, P.F.E. (1998): Funktionen im Wandel: Das neue Verhältnis von Arbeiten und Lernen in einer wissensstrukturierten Praxis, in: Innovationsforschung und Technologiemanagement, Berlin, Heidelberg: Springer, 89-104.

Sonntag, K./Schaper, N. (1999): Förderung beruflicher Handlungskompetenz, in: Personalentwicklung in Organizationen, 2nd Edition, Göttingen: Hogrefe, 211-244.

Spirtes, P./Richardson, T./Meek, C./Scheines, R./Glymour, C. (1998): Using path diagrams as a structural equation modeling tool, in: Sociological Methods \& Research, 27, 2, 182225.

Statistical Office of the Republic of Slovenia (2009): The average age of Slovene top managers in year 2000 and 2008. Special report, Ljubljana.

Tidd, J. (ed.) (2006): From knowledge management to strategic competency: Measuring technological, market and organisational innovation, London: World Scientific.

Woodruffe, C. (1993): What is meant by a competency?, in: Leadership \& Organization Development Journal, 14, 1, 29-36. 